ISSN : 2580-3220, E-ISSN : 2580-4588

J. Mandiri., Vol. 5, No. 2, Desember 2021 (77 - 85)

(C)2017 Lembaga Kajian Demokrasi

dan Pemberdayaan Masyarakat (LKD-PM)

DOI: https://doi.org/10.33753/mandiri.v5i2.178

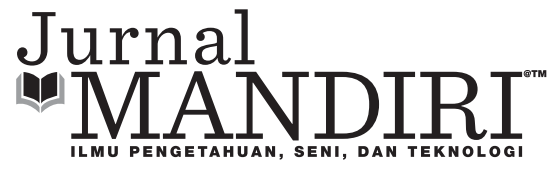

\title{
The Effects of Inflation, Interest Rates and Exchange Rates on Composite Stock Price Index During the Covid-19 Pandemic
}

\author{
Ifa Nurmasari \\ Fakultas Ekonomi dan Bisnis, Universitas Pamulang \\ dosen01550@unpam.ac.id \\ Siti Nur'aidawati \\ Fakultas Ekonomi dan Bisnis, Universitas Pamulang \\ dosen01867@unpam.ac.id
}

\begin{abstract}
The COVID-19 pandemic that hit Indonesia and even the world, caused changes in various sectors and decline in the Indonesian economy. To improve the economy, it is necessary to increase investment. This research aims to find out how the influence of inflation, bank interest rates and currency rates on Composite Stock Price Index both partially and simultaneously at the time of the covid-19 pandemic. The research method used in this study is quantitative descriptive, which discusses the problems faced that describe the state of a country expressed in numbers. The data used in this study is secondary data. It was taken during the covid-19 period from March 2020 to July 2021 . The analytical methods are used multiple linear regression, classical assumption test, hypothesis test, and determination coefficient test. The novelty of this research is to use macroeconomic data during the COVID-19 pandemic. The results showed that simultaneously, inflation, bank interest rates, and currency rates had a significant effect on Composite Stock Price Index. Inflation, bank interest rates, and currency rates exert a 94.9\% effect on Composite Stock Price Index. The remaining 5.1\% was affected by other factors not used in the study. Partially, inflation is positive and significant to Composite Stock Price Index. Bank interest rates and currency rates negatively and significantly affect Composite Stock Price Index.
\end{abstract}

Keywords : Inflation, Interest Rates, Exchange Rates, Composite Stock Price Index, Covid-19

\section{INTRODUCTION}

The covid-19 pandemic that hit around the world began in the Chinese city of Wuhan in late 2019. The covid-19 pandemic entered Indonesia in early 2020. Many changes are happening in various sectors, both economic, social, education caused by the covid-19 pandemic. According to Nurmasari (2020) the covid 19 pandemic has an impact on stock prices and transaction volume at one of the retail companies in Indonesia.

The existence of the covid-19 pandemic, causing activities in various sectors to change. To avoid spreading the virus, the government stipulates to always adhere to health protocols, ban gatrherings, conduct social distancing and wash hands properly. As a result, many people who just stay at home, go out for important purposes only. In the field of Education, which originally studied in school turned into learning from home. In the economic field, office workers as much as possible work from home, restaurants are empty of visitors, many daily workers 
experience a decrease in income. This causes income to be reduced even there are companies that make layoffs on their employees.

According to BPS data, indonesia's economy based on Gross Domestic Product in the second quarter of 2019 to the second quarter of 2020 decreased by $5.32 \%$ (y-on-y), while in the third quarter of 2019 to the third quarter of 2020 decreased by $3.49 \%$ (y-on-y), it is certain that Indonesia is currently experiencing recession.

Efforts that can be done to improve the Indonesian economy and get out of the recession, the government can encourage investment in Indonesia during the covid-19 pandemic. Investment in Indonesia has decreased, especially after the announcement of the first case of covid-19, namely on March 2, 2020. This can be seen in table 1, Composite Stock Price Index. From the table we can see that there has been a significant decline of Composite Stock Price Index value, especially on March 2, 2020.

Table 1. Composite stock price index

\begin{tabular}{cc}
\hline Date & $\begin{array}{c}\text { Composite Stock Price } \\
\text { Index (Rupiah) }\end{array}$ \\
\hline 25 February 2020 & $5.787,14$ \\
26 February 2020 & $5.688,92$ \\
27 February 2020 & $5.535,69$ \\
28 February 2020 & $5.452,70$ \\
2 March 2020 & $4.531,91$ \\
3 March 2020 & $4.531,90$ \\
4 March 2020 & $4.531,89$ \\
5 March 2020 & $4.531,88$ \\
6 March 2020 & $4.531,87$ \\
\hline
\end{tabular}

Source: Yahoo finance.

Sukirno (2015:165) states that inflation is a general and continuous increase in the price of goods. Meanwhile, Bank Indonesia provides an understanding of inflation, namely the increase in prices in general and continuously. An increase of one or two goods alone cannot be called inflation unless it extends (or results in a price increase) in another. The opposite of inflation is called deflation.

Inflation figures are calculated based on index numbers collected from several kinds of goods traded in the market with each price level (these goods are of course the most numerous and are the main basic needs for the community). Based on price data, a number is compiled in the index. Index figures that take into account all goods purchased by consumers at each price are referred to as the consumer price index (CPI). Based on the consumer price index can be calculated how much the rate of increase in prices in general in a given period. In addition to using CPI, the inflation rate can also be calculated using GNP or GDP deflator, i.e. comparing GNP or GDP measured based on prevailing price (GNP or nominal GDP) against GNP or constant price GDP (GNP or GDP riel).

Inflation can disrupt economic stability where economic actors are reluctant to speculate in the economy. In addition, inflation can also worsen the level of public welfare due to the decrease in people's purchasing power in general due to rising prices. In addition, the distribution of income is getting worse because not everyone can adjust to the inflation that occurs. Inflation has a positive impact and a negative impact depends on whether or not inflation is severe. If inflation is mild, it has a positive influence in the sense that it can encourage the economy better, namely increasing national income and making people passionate about working, saving, and making investments. Conversely, in times of severe inflation, i.e. when there is uncontrolled inflation (hyperinflation), the state of the economy becomes chaotic and the economy is felt sluggish. People become discouraged from work, saving, or making investments and production as prices rise rapidly. Permanent income earners such as civil servants or private employees and workers will also be overwhelmed to bear and offset prices so that their lives become worse and worse over time.

Interest rates according to Boediono (2014:76) are "the price of the use of loanable funds. Interest rates are one of the indicators in determining whether someone will make an investment or save." It can be said that this interest rate is the price of the loan. Interest rate is expressed as the percentage of principal money per unit of time. 
For people who borrow money, interest is a fine that must be paid to consume income before it is received. For the person giving the loan, interest is a reward for delaying consumption now until the time of the receivable. Bank interest can be interpreted as a return of services provided by banks based on conventional principles to customers who buy or sell their products.

In daily banking activities, there are two types of interest given by customers, namely: Deposit Interest is interest given as stimulation or, reply to services for customers who keep their money in the bank. Interest on deposits is the price that the bank must pay, to its customers. For example, checking services, savings interest, and deposit interest. The second is the interest on the loan, which is the interest given to the borrowers or the price to be paid by the borrower's customer to the bank. For example, credit interest.

An exchange rate is the price of a currency in a country as measured by the currency of another country. Or literally, the exchange rate of the currency that faces the situation of the country. Sukirno (2015:397), defines the foreign exchange rate or exchange rate as the amount of domestic money needed, i.e. the number of rupiahs needed, to obtain a unit of foreign currency. There are two types of exchange rates that apply in foreign exchange transactions, namely the selling rate or selling rate and the buying rate or buying rate. According to Hady (2016:70), the determination of the selling rate and buying rate will always be seen in terms of the interests of the bank. The selling rate of a currency will always be higher than its buying rate. This is because when viewed from the bank side, the bank always tries to profit from the difference between sale and purchase or what is known as the spread.

According to Hady, (2016:71), in the forex exchange is known two types of forex quotation, namely direct quotation and indirect quotation. Direct Quotation indicates the value of a country's currency (domestic currency) needed or obtained for one foreign currency value. An exchange rate is the price of a currency relative to the currency of another country. Exchange rates play an important role in spending decisions because they allow us to translate prices from different countries into the same language. Sukirno (2015: 397) explains "The exchange rate or often called the exchange rate is the price of the currency against other currencies. The exchange rate is one of the most important prices in an open economy, given the enormous influence on the current account balance and other macroeconomic variables."

The Composite Stock Price Index (JCI, also called Indonesia Composite Index, ICI, or IDX Composite) is one of the stock market indices used by the Indonesia Stock Exchange (IDX). JCI was first introduced on April 1, 1983, as an indicator of stock price movements in the JCI. This index includes price movements of all common shares and preferred shares listed on the IDX. Composite Stock Price Index is used to determine the development and general situation of the capital market. Composite Stock Price Index does not indicate the situation of a particular company but measures the performance value of all shares listed on a stock exchange.

Composite Stock Price Index can be used to assess the general market situation and also to measure whether the stock price is rising or decreasing. Composite Stock Price Index uses all stock prices listed on the Indonesia Stock Exchange. For JCI to describe reasonable market conditions, the Indonesia Stock Exchange is authorized to issue or not include one or more Listed Companies from the calculation of Composite Stock Price Index. The basis of consideration, among others, is if the number of shares of the Listed Company owned by the public (free float) is relatively small while the market capitalization is large enough so that changes in the listed company's stock price have the potential to affect the fairness of Composite Stock Price Index movements.

The calculation of Composite Stock Price Index is no different from the calculation of individual stock price indices. It's just that, in the calculation of Composite Stock Price Index, we have to sum up the entire existing stock price (listing). The general formula for calculating Composite Stock Price Index, namely:

Composite Stock Price Index $=\frac{\text { total share price at the time of effect }}{\text { total share price at the base time }} \times 100 \%$ 
If the Composite Stock Price Index is above $100 \%$, it means that the market conditions are in a crowded state, conversely, if the Composite Stock Price Index is below the $100 \%$ mark, then the market is in the doldrums. If the Composite Stock Price Index properly points to the number $100 \%$, then the market is in a stable state.

Movement (Composite Stock Price Index) is influenced by several factors, such as factors originating from within the country and factors originating from abroad. Factors originating from within the country can come from fluctuations in the exchange rate of a country against another country, inflation rate, interest rates, economic growth, social conditions, politics, security of a country, and so on. While the factors that come from abroad come from stock exchanges that have a strong influence on other countries' stock exchanges are stock exchanges that belong to developed countries such as America, Japan, The United Kingdom, and so on. The internal impact that affects Composite Stock Price Index is inflation will have a positive and negative impact on Composite Stock Price Index. Inflation negatively impacts inflation if it reduces investor income, while positively affects inflation when inflation will increase investor income. The positive impact of inflation causes the circulation and faster turnover of goods in society so that the production of goods increases and the profits of entrepreneurs increase.

This research is important to know what factors affect investment in Indonesia during the covid-19 pandemic. Thus the results of this study can provide input to the government in setting macro policies appropriately to be able to encourage investment Composite Stock Price Index in Indonesia. With more and more investors who want to invest, it is expected to improve the Indonesian economy.

Research the effect of macroeconomics on Composite Stock Price Index has been done before. According to Tammu (2020), inflation has no effect on the ihsg. However, according to Ningsih \& Waspada (2018) and Ni Wayan Sri Asih \& Akbar (2016), inflation has an effect on stock prices. According to Harsono \& Wonokinasih (2018), interest rate has an effect on Composite Stock Price Index. Meanwhile, according to Sartika (2017), interest rates have no effect on Composite Stock Price Index. According to Zuhri et al. (2019), the currency exchange rate has no effect on Composite Stock Price Index. Meanwhile, according to Astuti et al. (2016), the currency exchange rate has an effect on Composite Stock Price Index. From the results of the research that has been done, it shows that the results of this study are still not consistent, so it is necessary to do this research.

\section{METHODS}

The object used in this study is Indonesian macroeconomic data. The data taken is monthly data during the covid-19 pandemic, which is from March 2020 to June 2021 which has been published through the BPS and Bank Indonesia (BI) websites. This research is descriptive associative, which is a form of research using at least two or more variables that are connected. The associative method used is a causal relationship that is a causal relationship between independent variables and dependent variables.

The independent variables used are inflation, interest rates, and exchange rates. Independent variables are variables that are affected or that are a result, because of the existence of free variables. The dependent variable used in the study was the Composite Stock Price Index.

The data analysis method is a method used in processing research data to obtain a conclusion. The types of data and hypotheses are decisive in the accuracy of the statistical selection of test tools. Data analysis is an activity after data from all respondents or other data sources is collected.

The systematics of the analysis used in this study are as follows: Descriptive statistical analysis, multiple linear regression analysis. The multiple linear regression equations in this study can be formulated as follows: $\mathrm{Y}=\mathrm{a}+\mathrm{b} \_1 \mathrm{X} \_1+\mathrm{b} \_2$ X_2+b_3 X_3

Where $\mathrm{Y}=$ Composite Stock Price Index, a is constant, $\mathrm{b} 1, \mathrm{~b} 2, \mathrm{~b} 3$ is regression coefficient, $\mathrm{X} 1$ is inflation, $\mathrm{X} 2$ is bank rate, $\mathrm{X} 3$ is the currency exchange rate. The classical assumption test is performed to find out the condition of the 
data used in the study. Classical assumption tests are normality test, multicollinearity test, heteroskedasticity test, and autocorrelation test.

Hypothesis analysis is done to test whether the hypothesis in this study is accepted or rejected. The hypothesis tests used are simultaneous tests (Test $\mathrm{F})$ and partial tests (t-tests). The $\mathrm{F}$ test is performed to determine whether all independent variables simultaneously exert a significant effect on dependent variables. Partial Test (Test $t$ ) is done by comparing t count with $t$ table. The Coefficient of Determination test is used to determine how much the percentage of the influence of independent variables contributes to dependent variables. If the value of the coefficient of determination is close to 1 , it means that the independent variable has a major effect on the dependent variable. If the coefficient of determination value gets a result of 0 , it means that the independent variable does not effect on the dependent variable.

\section{RESULTS}

Descriptive statistics research is done to describe or describe the results of variables that have been processed using SPSS (Statistic Product and Service Solution) version 20. The data is displayed in table 2. The data used here are 16 from March 2020 to June 2021. Inflation has a maximum value of 2.96 and a minimum of 1.32 . The interest rate has a maximum value of 4.5 and the minimum value is 3.5 . The lowest currency rate is at 14,020 and the highest is at 16,300. The lowest Composite Stock Price Value is at 4,538.93 and the highest value is at 6,241.80.
This data meets the classic assumption test. Residualized normal anesthetic, this can be seen from table 3. One Sample KolmogorovSmirnov Test. The value at Asymp. sig (2-tailed) is 0.200 , greater than 0.05 . The results of the Multicollinearity test can be seen in table 4. If the tolerance value is above 0.10 and the VIF value is below 10 then there are no symptoms of multicollinearity. The results showed that the value tolerance variable inflation, interest rate, and exchange rate were at $0.304 ; 0.372$, and 0.562 . While the VIF value of inflation, interest rates, and exchange rates is $3,290,2,689$, and 1,780 .

Table 3. Normality test

\begin{tabular}{|c|c|c|}
\hline & ple Kolmogorov & $\begin{array}{l}\text { Smirnov Test } \\
\text { Unstandard- } \\
\text { ized Residual }\end{array}$ \\
\hline \multirow[t]{6}{*}{$\mathrm{N}$} & & 16 \\
\hline & Mean & .0000000 \\
\hline & Std. Deviation & 129.06318410 \\
\hline & Absolute & .117 \\
\hline & Positive & .117 \\
\hline & Negative & -.103 \\
\hline \multicolumn{2}{|c|}{ Test Statistic } & .117 \\
\hline \multicolumn{2}{|c|}{ Asymp. Sig. (2-tailed) } & $.200^{\mathrm{c}, \mathrm{d}}$ \\
\hline \multicolumn{3}{|c|}{ a. Test distribution is Normal. } \\
\hline \multicolumn{3}{|c|}{ b. Calculated from data. } \\
\hline \multicolumn{3}{|c|}{ c. Lilliefors Significance Correction. } \\
\hline
\end{tabular}

Source: SPSS, 2021.

Table 4. Multicollinearity test

Table 2. Descriptive statistical test

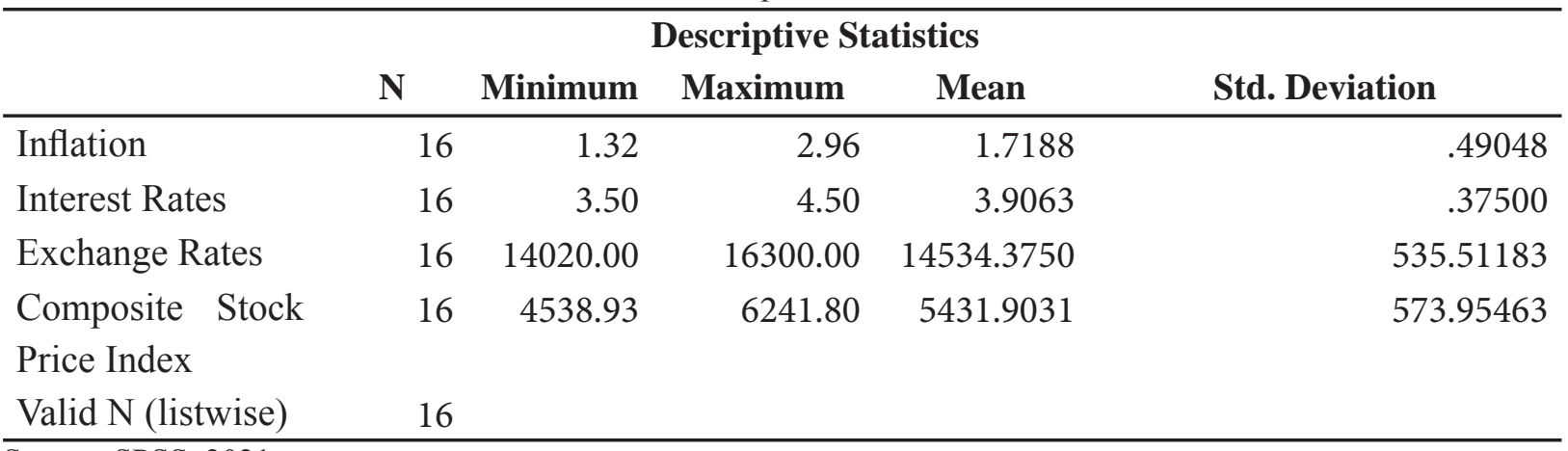

Source: SPSS, 2021 
Table 4. Multicollinearity test

\begin{tabular}{lcc}
\hline \multicolumn{1}{c}{ Model (Constant) } & Tolerance & VIF \\
\hline Inflation & .304 & 3.290 \\
Interest Rates & .372 & 2.689 \\
Exchange Rates & .562 & 1.780 \\
\hline
\end{tabular}

a. Dependent Variable: Composite Stock Price Index

Source: SPSS, 2021.

Table 5. Glejser test

\begin{tabular}{|c|c|c|c|c|c|c|c|}
\hline \multirow[b]{3}{*}{ Model } & \multicolumn{6}{|c|}{ Coefficients $^{\mathrm{a}}$} & \\
\hline & \multicolumn{2}{|c|}{$\begin{array}{l}\text { Unstandardized } \\
\text { Coefficients }\end{array}$} & \multirow{2}{*}{$\begin{array}{c}\text { Standardized } \\
\text { Coefficients } \\
\text { Beta }\end{array}$} & & \multirow[b]{2}{*}{ Sig } & \multicolumn{2}{|c|}{ Collinearity Statistics } \\
\hline & B & Std. Error & & & & Tolerance & VIF \\
\hline 1(Constant) & 919.760 & 681.203 & & 1.350 & .202 & & \\
\hline Inflation & 18.508 & 72.528 & .125 & .255 & .803 & .304 & 3.290 \\
\hline Interest Rates & 12.438 & 85.770 & .064 & .145 & .887 & .372 & 2.689 \\
\hline Exchange Rates & -.062 & .049 & -.453 & -1.263 & .231 & .562 & 1.780 \\
\hline
\end{tabular}

a. Dependent Variable: Abs_RES

Source: SPSS, 2021.

Table 6. Durbin-watson test and coefficient of determination

\begin{tabular}{crrrrr}
\hline \multirow{2}{*}{ Model } & \multirow{2}{*}{ R } & & \multicolumn{4}{c}{ Model Summary } \\
R Square & $\begin{array}{c}\text { Adjusted R } \\
\text { Square }\end{array}$ & $\begin{array}{l}\text { Std. Error of } \\
\text { the Estimate }\end{array}$ & Durbin-Watson \\
\hline 1 & $.974^{\text {a }}$ & .949 & .937 & 144.29703 & 2.261 \\
\hline
\end{tabular}

a. Predictors: (Constant), Inflation, Interest Rates, Exchange Rates

b. Dependent Variable: Composite Stock Price Index

Source: SPSS, 2021.

Table 7. Multiple regression analysis

\begin{tabular}{|c|c|c|c|c|c|c|c|}
\hline \multirow[b]{3}{*}{ Model } & \multicolumn{5}{|c|}{ Coefficients $^{\mathrm{a}}$} & \multirow{2}{*}{\multicolumn{2}{|c|}{$\begin{array}{c}\text { Collinearity } \\
\text { Statistics }\end{array}$}} \\
\hline & \multicolumn{2}{|c|}{$\begin{array}{l}\text { Unstandardized } \\
\text { Coefficients }\end{array}$} & \multirow{2}{*}{$\begin{array}{c}\text { Standardized } \\
\text { Coefficients } \\
\text { Beta } \\
\end{array}$} & \multirow[b]{2}{*}{$\mathbf{t}$} & \multirow[b]{2}{*}{ sig } & & \\
\hline & B & Std. Error & & & & Tolerance & VIF \\
\hline 1 (Constant) & 15049.721 & 1294.030 & & 11.630 & .000 & & \\
\hline Inflation & 409.770 & 137.776 & .350 & 2.974 & .012 & .304 & 3.290 \\
\hline Interest Rates & -1668.268 & 162.931 & -1.090 & -10.239 & .000 & .372 & 2.689 \\
\hline Exchange Rates & -.262 & .093 & -.244 & -2.821 & .015 & .562 & 1.780 \\
\hline
\end{tabular}

a. Dependent Variable: Composite Stock Price Index

Source: SPSS, 2021.

Based on the results of the heteroskedasticity test can be seen in table 5 using the Glejser test. In the test, the signification value of the variables of inflation, interest rates, and exchange rates is $0.803 ; 0.887$, and 0.231 . The value exceeds 0.05 , so there is no heteroskedasticity. For autocorrelation, test results can be seen in table
6. Durbin-Watson (d) was 2,261. The dl and du scores in this study were 0.8572 and 1.7277 , of 1.7277, were. The Durbin-Watson score is between du and 4-du, which is $1.7277 \leq 2.261 \leq$ 2.272. The Durbin-Watson test showed that the regression model did not autocorrelate.

Based on the table of multiple regression test results 
from the research data conducted, the following equations are obtained: $\mathrm{Y}=15049,721+409,770$ $\mathrm{X} 1-1668,268 \mathrm{X} 2-0.262 \mathrm{X} 3$. These results showed that inflation has a positive influence on Composite Stock Price Index. While interest rates and currency rates have a negative or opposite influence on Composite Stock Price Index. To test the simultaneous influence of free variables on bound variables can be seen in table 8 . The results of the $F$ test showed a calculated $F$ value of 75.106 , with a table $F$ value of 3.81 and a significance value of $0.000<0.05$. Based on these results obtained by inflation, interest rates and currency rates have a significant effect simultaneously on Composite Stock Price Index during the Covid 19 pandemic.

Based on the Determination Coefficient test table, the R Square value of 0.949 or $94.9 \%$ can be interpreted so that the percentage of independent variable contribution in the form of inflation, interest rates, and currency rates that affect the dependent variables of on Composite Stock Price Index is $94.9 \%$ while the remaining $5.1 \%$ is influenced by other variables not studied in this research model.

\section{DISCUSSION}

The results showed that inflation had a significant positive effect on Composite Stock Price Index during covid-19. This is indicated by the signification value of inflation of $0.012<0.05$ and t-calculate inflation of 2,974 $>$ t-table (2.12). The greater inflation will cause an increase in the value of on Composite Stock Price Index. At the time of the covid-19 pandemic, the inflation rate ranged from $1-3 \%$. If there is inflation of $1-3 \%$, it means that the price of goods has increased by $1-3 \%$. The company's profits will be even greater. The company's opportunity to pay dividends is also getting bigger. So it attracts infestors to infest. The increase in the price of these goods encourages investors to invest because they want an increase in profits. The results of this study are in accordance with the results of Rizky et al. (2019), Astuti et al. (2016) dan Ni Wayan Sri Asih Masithah Akbar (2016).

During Covid-19, interest rates have a negative and significant effect on Composite Stock Price Index. The interest rate sign value of $0.00<0.05$ and the t-calculated value of the interest rate of $10,239>$ t-table (2.12). The greater the interest rate will cause a decrease in the value of Composite Stock Price Index during the covid-19 pandemic. The lower value of interest rates, causing investors prefer to invest. By investing the profits are obtained greater than if the money is saved in the bank. The results of this study are in accordance with the results of Sari (2019), Ningsih \& Waspada (2018), Melyani \& Esra (2021), Tammu (2020) and Harsono \& Wonokinasih (2018). However, the results of this study are not in accordance with the results of Sartika (2017).

Currency exchange rates have a negative and significant effect on Composite Stock Price Index. The sign value of this currency rate is $0.015<0.05$. The $t$-calculated value of the currency rate is 2,821 $>2.12$ ( $\mathrm{t}$-table). The greater the currency rate will cause a decrease in the value of Composite Stock Price Index during the Covid 19 pandemic. At the time the covid-19 pandemic hit Indonesia, the level of foreign confidence to invest in Indonesia was low. As a result, even if the rupiah exchange rate rises, or the rupiah weakens, foreign investors are reluctant to invest in Indonesia. This causes the demand for shares to decrease so that the stock price becomes down. The results of this study,

Table 8. Simultan test (F-test)

\begin{tabular}{lrrrrrr}
\hline \multicolumn{1}{c}{ Model } & Sum of Squares & df & Mean Square & \multicolumn{1}{c}{ F } & \multicolumn{1}{c}{ Sig. } \\
\hline 1 Regression & 4691499.138 & & 3 & 1563833.046 & 75.106 & $.000^{\mathrm{b}}$ \\
Residual & 249859.582 & & 12 & 20821.632 & & \\
Total & 4941358.721 & & 15 & & & \\
\hline
\end{tabular}

a. Dependent Variable: Composite Stock Price Index

b. Predictors: (Constant), Inflation, Interest Rates, Exchange Rates

Source: SPSS, 2021. 
in accordance with research from Dewi (2020), Husnul et al. (2017), Saputra (2019), Ni Wayan Sri Asih Masithah Akbar (2016) and Harsono \& Wonokinasih (2018).

Based on $\mathrm{F}$ test results showed the value of F-count (75.106) is greater than the F-table value of 3.81 and the value of significance of $0.000<$ 0.05 . Based on these results obtained by inflation, interest rates and currency rates have a significant effect simultaneously on Composite Stock Price Index during the covid-19 pandemic. The percentage of independent variable contributions in the form of inflation, interest rates, and currency rates can affect dependent variables in the form of Composite Stock Price Index by $94.9 \%$ while the remaining $5.1 \%$ is influenced by other variables not studied in this study. Therefore, during the covid-19 pandemic, to be able to increase investment in Indonesia, the government needs to pay attention and regulate macroeconomic values such as inflation, interest rates, and currency rates.

\section{CONCLUSION}

Based on the results of research that has been conducted on inflation variables, interest rates and currency rates against Composite Stock Price Index at the time of the covid 19 pandemic, it can be concluded that both partially and simultaneously, inflation variables, interest rates and currency rates have a significant effect on Composite Stock Price Index. Inflation has a positive effect on Composite Stock Price Index, while interest rates and currency rates negatively affect Composite Stock Price Index. Variable inflation, interest rates and currency rates affect Composite Stock Price Index of 94.9\%.

Based on the research that has been done, there are several suggestions that can be considered so that the value of investment increases. To increase the value of such investments, the government should pay attention to macroeconomic variables, such as inflation, interest rates, and currency rates. This study has limitations in terms of the number of free variables that can affect Composite Stock Price Index. For further research, it is expected to add the number of free variables used to find out what factors can affect Composite Stock Price Index during covid 19.

\section{REFERENCES}

Apa Itu Inflasi. (n.d.). https://www.bi.go.id/id/ fungsi-utama/moneter/inflasi/Default.aspx.

Astuti, R., Lapian, J., Rate, P. Van, Manajemen, J., Bisnis, E., \& Ratulangi, U. S. (2016). Pengaruh Faktor Makro Ekonomi Terhadap Indeks Harga Saham Gabungan (Ihsg) Di Bursa Efek Indonesia (Bei) Periode 20062015. Jurnal Berkala Ilmiah Efisiensi, 16(2), 399-406.

Boediono. (2014). Ekonomi Internasional Pengantar Ilmu Ekonom (3 (Ed.)). BPFE UGM.

BPS. (n.d.). Retrieved November 10, 2020, from http://www.bps.go.id/BPS. (n.d.). No Title. Retrieved November 10, 2020, from http:// www.bps.go.id/.

Dewi, I. P. (2020). PENGARUH INFLASI, KURS, DAN HARGA MINYAK DUNIA TERHADAP INDEKS HARGA SAHAM GABUNGAN DI BURSA EFEK INDONESIA. Jurnal Ilmu Manajemen, 17(1), $10-19$.

Hady, H. (2016). Manajemen Keuangan Internasional. Mitra Wacana Media.

Harsono, A. R., \& Wonokinasih, S. (2018). Pengaruh Inflasi, Suku Bunga, Dan Nilai Tukar Rupiah Terhadap INdeks Harga Saham Gabungan (Studi pada Bursa Efek Indonesia Periode 2009-2013 ). Jurnal Administrasi Bisnis, 60(2), 102-110.

Husnul, H. M., Hidayat, R. R., \& Sulasmiyati, S. (2017). Analisis pengaruh inflasi, kurs (IDR/USD), Produk Domestik Bruto dan harga emas dunia terhadap Indeks Harga Saham Gabungan. Jurnal Administrasi Bisnis, 53(1), 66-74. http://administrasibisnis. studentjournal.ub.ac.id/index.php/jab/article/ view/2183.

Melyani, I., \& Esra, M. A. (2021). Pengaruh Inflasi, Suku Bunga Dan Nilai Tukar Rupiah Terhadap Return Saham. Jurnal Ilmiah Manajemen Dan Bisnis, 6(1), 50. https://doi. org/10.31851/neraca.v5i1.5630. 
Ni Wayan Sri Asih, \& Akbar, M. (2016). Analisis Pengaruh Inflasi, Suku Bunga, Nilai Tukar (Kurs) Dan Pertumbuhan Produk Domestik Bruto (Pdb) Terhadap Indeks Harga Saham Gabungan (Ihsg) Studi Kasus Pada Perusahaan Properti Yang Terdaftar Di Bursa Efek Indonesia. Jurnal Manajemen Dan Akuntansi, 17(1), 43-52.

Ningsih, M. M., \& Waspada, I. (2018). PENGARUH BI RATE DAN INFLASI TERHADAP INDEKS HARGA SAHAM GABUNGAN (Studi Pada Indeks Properti, Real Estate, Dan Building Construction, di BEI Periode 2013 - 2017). Jurnal MANAJERIAL, 17(2), 247. https://doi.org/10.17509/ manajerial.v17i2.11664.

Nurmasari, I. (2020). Dampak Covid-19 Terhadap Perubahan Harga Saham dan Volume Transaksi (Studi Kasus Pada PT. Ramayana Lestari Sentosa, Tbk.). Jurnal SEKURITAS (Saham, Ekonomi, Keuangan Dan Investasi), 3(3), 230. https://doi.org/10.32493/skt.v3i3.5022.

Rizky, I. A., Amin, M., \& Mawardi, C. M. (2019). Pengaruh Nilai Tukar, Suku Bunga SBI, Inflasi dan Pertumbuhan GDP terhadap Pergerakan IHSG di Bursa Efek Indonesia. E-Jra, 08(05), 20-30.

Saputra, A. (2019). Pengaruh Nilai Tukar, Suku Bunga Dan Inflasi Terhadap Indeks Harga
Saham Gabungan Di Bursa Efek Indonesia. Journal of Islamic Economic and Banking, 2(2), 1-15.

Sari, W. I. (2019). Analisis Pengaruh Inflasi, Suku Bunga SBI, Nilai Tukar Terhadap Return LQ 45 dan Dampaknya Terhadap Indeks Harga Saham Gabungan (IHSG) di Bursa Efek Indonesia (BEI). Jurnal SEKURITAS (Saham, Ekonomi, Keuangan Dan Investasi), 3(1), 65. https://doi.org/10.32493/skt.v3i1.3263.

Sartika, U. (2017). Pengaruh Inflasi, Tingkat Suku Bunga, Kurs, Harga Minyak Dunia Dan Harga Emas Dunia Terhadap Ihsg Dan Jii Di Bursa Efek Indonesia. BALANCE Jurnal Akuntansi Dan Bisnis, 2(2), 285. https://doi. org/10.32502/jab.v2i2.1180.

Sukirno, S. (2015). Makroekonomi Teori Pengantar Edisi Ketiga. PT Raja Grafindo Persada.

Tammu, R. G. (2020). Pengaruh Inflasi dan Suku Bunga Bank Indonesia Terhadap Indeks Harga Saham Gabungan ( IHSG ) Periode 2014 2018. Jurnal Of Economic, Management, And Accounting, 3(1), 62-66.

Zuhri, S., Hufron, M., \& Mustapita, A. F. (2019). Pengaruh Inflasi, kurs, dan BI Rate terhadap Indeks Harga Saham Gabungan Bursa Efek Indonesia (BEI) Periode 2014 - 2018. E-Jurnal Riset Manajemen, 41-55. 